\title{
Trade of parrots in urban areas of Madagascar
}

\author{
Kim E. Reuter', Tara A. Clarkel", Marni LaFleur'II, Lucia \\ RodriguezIV , Sahondra Hanitriniainalv and Melissa S. \\ Schaeferiv
}

\begin{abstract}
The live capture of parrots is causing increasing concern across Africa. In Madagascar, home to three species of parrot (Coracopsis nigra, C. vasa, Agapornis canus), no study has examined how these species are being extracted from the wild and traded. In this study, we examined the procurement, length of ownership, and the end of ownership of pet parrots. Data were collected via household surveys ( $n=440$ interviews in 9 towns), market visits ( $n=17$ markets in 6 towns), and opportunistic data collection methods in urban, Malagasy towns. Most Coracopsis spp. are purchased (59\%) or captured directly by the owner from the wild (22\%), although we were unable to determine how A. canus was procured. Survey respondents reported purchasing coracopsis spp. for the price of USD $5.36 \pm 3.20$. The average Coracopsis spp. was kept in captivity for $3.17 \pm 2.51$ years. No survey respondents provided information on the purchase price or length of ownership for A. canus. Ownership ended primarily when Coracopsis spp. escaped/flew away (36\%) or died of unknown causes (21\%). A. canus also flew away, although this was only reported in one instance. In-country demand appears to be met by a trade network of both informal and formal actors. It is unclear whether current protections for Madagascar's parrots, as far as the domestic market is concerned, are sufficient to ensure sustainable extraction of live individuals.
\end{abstract}

\section{RÉSUMÉ}

La capture de perroquets vivants est une préoccupation grandissante en Afrique. À Madagascar, qui abrite trois espèces de perroquets (Coracopsis nigra, C. vasa, Agapornis canus), aucune étude n'a examiné la manière dont ces espèces sont extraites de la nature et vendues et achetées. Dans cette étude, nous avons examiné l'acquisition, la durée de possession, et la fin de possession des perroquets domestiques. Les données ont été collectées grâce à des études dans les ménages ( $n=440$ enquêtes dans 9 villes), des visites dans les marchés ( $n=17$ marchés dans 6 villes), et à une collecte de données opportunistes dans des zones urbaines malgaches. La plupart des coracopsis sont achetés (59\%) ou extraites directement de la nature par les propriétaires (22\%) ; il nous a été impossible de déterminer les moyens utilisés pour l'obtention d'A. canus. Les personnes interrogées ont

\author{
Correspondence: \\ Kim E. Reuter \\ Conservation International, Nairobi, Kenya \\ Email: kimeleanorreuter@gmail.com
}

déclaré l'achat des espèces de coracopsis pour la somme de $5,36 \pm 3,20$ dollars US. En moyenne, ces espèces ont été gardées en captivité pendant $3,17 \pm 2,51$ ans. Aucune personne interrogée n'a procuré d'information sur le prix d'achat ou la durée de possession pour A. canus. Pour les espèces de Coracopsis, la possession s'est principalement terminée lors de la fuite/l'envol (36\%) ou la mort liée à des causes inconnues (21\%). La fuite d'A. canus a également été déclarée, mais dans un cas seulement. La demande locale semble être satisfaite par un réseau commercial d'acteurs formels et informels. II n'est cependant pas encore clair si la protection des perroquets de Madagascar, permet que l'extraction de ces espèces pour le marché domestique soit menée de façon durable.

\section{INTRODUCTION}

Across the globe, 2,600 of the more than 9,600 bird species in existence are registered as being subject to trade (FAO 2011). The live capture of birds is causing increasing concern and parrot populations across Africa are declining (Martin et al. 2014). Parrots (Psittacidae) are among the most threatened group of bird species in the world, with $28 \%$ of species threatened on the IUCN Red List (Olah et al. 2016). In Ghana, 90-99\% of Grey parrot (Psittacus erithacus) populations have been extirpated in the last two decades, due to habitat change and degradation, and the trade (both domestic and international) of this species (Annorbah et al. 2016). In the Democratic Republic of Congo, the live capture of parrots for the international market has caused a decline in $P$. erithacus populations (Hart et al. 2016). Studies such as these have focused primarily on the international market and there are few studies examining the keeping of parrots as pets in countries where they are endemic (Drews 2001).

In Madagascar, home to the Black parrot (Coracopsis nigra), the Vasa parrot (C. vasa), and the endemic Grey-headed lovebird (Agapornis canus), the live capture of parrots has received little attention (Martin et al. 2014). To date, no study has examined how parrots in Madagascar are being extracted from the wild and traded, despite evidence that it is not uncommon for parrots to be kept as pets (Reuter et al. 2017). This is notable as the live capture of animals in Madagascar is causing increasing concern (Schwitzer et al. 2013). Amphibians and reptiles are captured, 


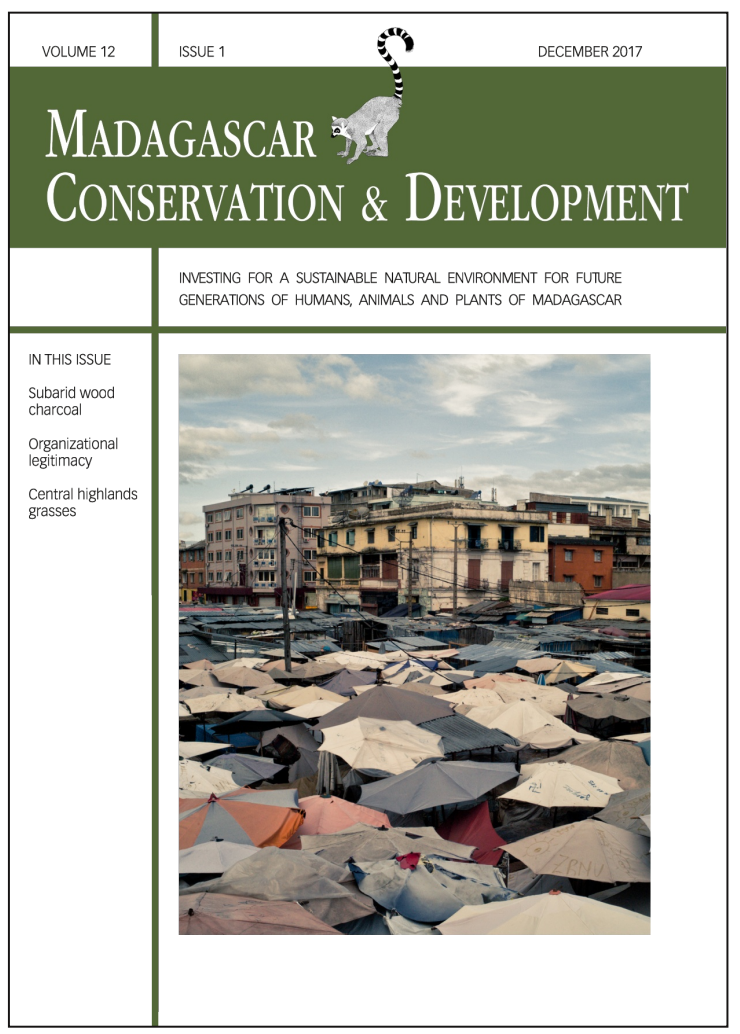

Madagascar Conservation \& Development is the journal of Indian Ocean e-Ink. It is produced under the respon-sibility of this institution. The views expressed in contri-butions to MCD are solely those of the authors and not those of the journal editors or the publisher.

All the Issues and articles are freely available at http://www.journalmcd.com

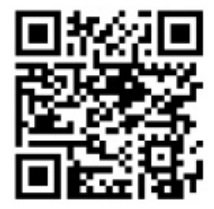

Contact Journal MCD

info@journalmcd.net for general inquiries regarding MCD funding@journalmcd.net to support the journal

Madagascar Conservation \& Development Institute and Museum of Anthropology

University of Zurich

Winterthurerstrasse 190

$\mathrm{CH}-8057$ Zurich

Switzerland

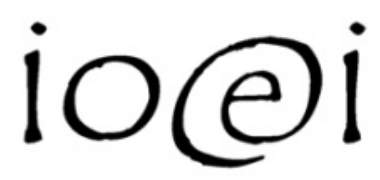

Indian Ocean e-Ink

Promoting African Publishing and Education

www.ioeink.com

Missouri Botanical Garden (MBG)

Madagascar Research and Conservation Program

Missouri Botanical Garden BP 3391

Antananarivo, 101, Madagascar 
sometimes to the point of near-extinction (e.g., Grenoble 2013) and transported internationally via organized trade networks (Andreone et al. 2005) for pet or medical/medicinal purposes. Similarly, lemurs are also often live captured for the pet trade; over 28,000 lemurs were estimated to be kept as illegal pets in urban households between 2010 and mid-2013 (Reuter et al. 2016a), with 30 species affected (Reuter and Schaefer 2016).

In Madagascar, the trade of parrots has been primarily recorded in anecdotal reports (McBride 1996) or in export databases (UNEP-WCMC 2016; but see Reuter et al. 2017). Though there is evidence to suggest widespread ownership of pet parrots in Madagascar (Reuter et al. 2017), there is little information on how these parrots are extracted from the wild and transported to areas where many pet owners live, such as in urban areas. One anecdotal report regarding the capture of Coracopsis vasa for the international pet trade, noted that exporters would pay USD 2.54 for one $C$. vasa (regardless of age or condition) captured in northeast Madagascar (McBride 1996). Parrots are occasionally consumed by some communities in Madagascar (McBride 1996, Gardner and Davies 2014). In the Kirindy forest, the number of Coracopsis spp. eaten for food exceeded those captured for the pet trade (Dowsett 2000, Ekstrom 2004). In contrast, C. vasa are not considered to be "edible" in western Madagascar south of Kirindy (Randrianandrianina et al. 2010). In this study, we aimed to increase understanding of the trade of the three parrot species in Madagascar, including procurement, length of ownership, and the end of ownership.

LEGALITY OF PARROT TRADE AND OWNERSHIP. A 2006 domestic law determined that CITES Appendix II species can only be extracted (captured or hunted) with a permit and within national quotas determined by the Malagasy government (quotas advised upon by the CITES Scientific Authority, Durbin 2007). The extraction of the species (even with a permit) may be further restricted to national hunting seasons (Randrianandrianina et al. 2010) which do not consider the biology of different species (Rakotoarivelo et al. 2011). Due to regulatory burdens and difficulty getting permits, most extraction likely occurs illegally (similar to bushmeat hunting, Golden et al. 2014) without permits (Rakotoarivelo et al. 2011).

International export of these species is regulated as they are listed in CITES Appendix II. A moratorium on trade of $C$. vasa was issued in 1995 (Martin et al. 2014) after the Malagasy government did not establish harvest quotas for export (though the primary threat to the species appeared to be habitat degradation, CITES 2008). There have been no reported exports of the species from Madagascar since 2000 (UNEP-WCMC 2016). For Coracopsis nigra, there have been no exports since 2006 (prior to which wild-caught individuals were exported for commercial reasons, UNEP-WCMC 2016). Wild-captured Agapornis canus continue to be exported for commercial reasons (as opposed to non-commercial, scientific, educational, zoo, breeding, or other purposes, UNEP-WCMC 2013) from Madagascar (750 individuals in 2013 and 300 in 2014, UNEPWCMC 2016); an annual export quota of 3,500 individuals was established in 1993 (CITES Notification No. 744). It is not clear whether there is substantial illegal export of the three species; a database on illegal animal seizures did not list Madagascar's parrot species (Wildlife Trade Tracker, http://wildlifetradetracker.org/). since $1981,4,242$ C. vasa, 5,875 C. nigra, and 117,549 A. canus have been reported to CITES as being exported (considering the larger of both exporter and importer-reported numbers, UNEPWCMC 2016).

\section{METHODS}

We employed various methods, including household surveys, market visits, and opportunistic data collection (detailed below). We present both qualitative and quantitative data from these data collection efforts.

ETHICAL RESEARCH STATEMENT. International standards for research ethics were followed and research was approved by an ethics oversight committee (Institutional Review Board, University of Utah). Research followed all national and local laws pertaining to the survey of adults in Madagascar. Research was authorized by locally elected officials in every town and commune in which research took place. This research required no government research permits.

STUDY SPECIES. We collected data regarding the following species: greater vasa parrot (Coracopsis vasa; Least Concern; decreasing population; BirdLife International 2016a), lesser vasa parrot (C. nigra; Least Concern; stable population size; BirdLife International 2016b), and the grey-headed lovebird (Agapornis canus; Least Concern; stable population size; BirdLife International 2016C). Though there are no published population estimates of these three species (BirdLife International 2016a,b,c), they are common across Madagascar (e.g., Martin et al. 2014).

All three species have plant-based diets (Hino 2002, Bollen and Elsacker 2004). In regards to habitat preference and range, Coracopsis vasa is considered edge-sensitive (Watson et al. 2004) and is found along coastal regions (BirdLife International 2016c). Coracopris nigra is not known to be edge-sensitive and is found in agricultural settings, forests, and grasslands (BirdLife International 2017b). Agapornis canus is found along Madagascar's coastal regions and has a large range that includes much of the country (BirdLife International 2016c). Although A. canus may be present in some agricultural landscapes and shrublands, their absence in edge or matrix habitats may indicate edge-sensitivity (Watson et al. 2004) and they are not typically found in forests (BirdLife International 2017).

STUDY AREA. Data were collected in ten urban towns throughout central, southern, and eastern Madagascar (Figure 1). Towns were always located within the habitat range of at least one of the three study species, had human populations ranging from 12,000 - 1.05 million people, and were found at altitudes ranging from sea-level to 1,500 meters (Table S1). Most of the urbans towns surveyed had daily open-air markets selling a range of animals.

Towns were selected at regular intervals for surveying along a 747-km highway 'transect' (following Reuter et al. 2016a,b) beginning in Toamasina (formerly known as Tamatave, eastern Madagascar) and going central/south via the RN2/RN7 roads down to the town of Fianarantsoa. In addition, the towns of Tôlanaro (formerly known as Fort-Dauphin) and Toliara (formerly known as Tulear) in the southern portions of the island were sampled; these towns were not sampled using our overland, 'transect' approach due to safety concerns regarding travel by car.

The towns selected for surveying included five of the seven largest towns in Madagascar (from largest to smallest: 


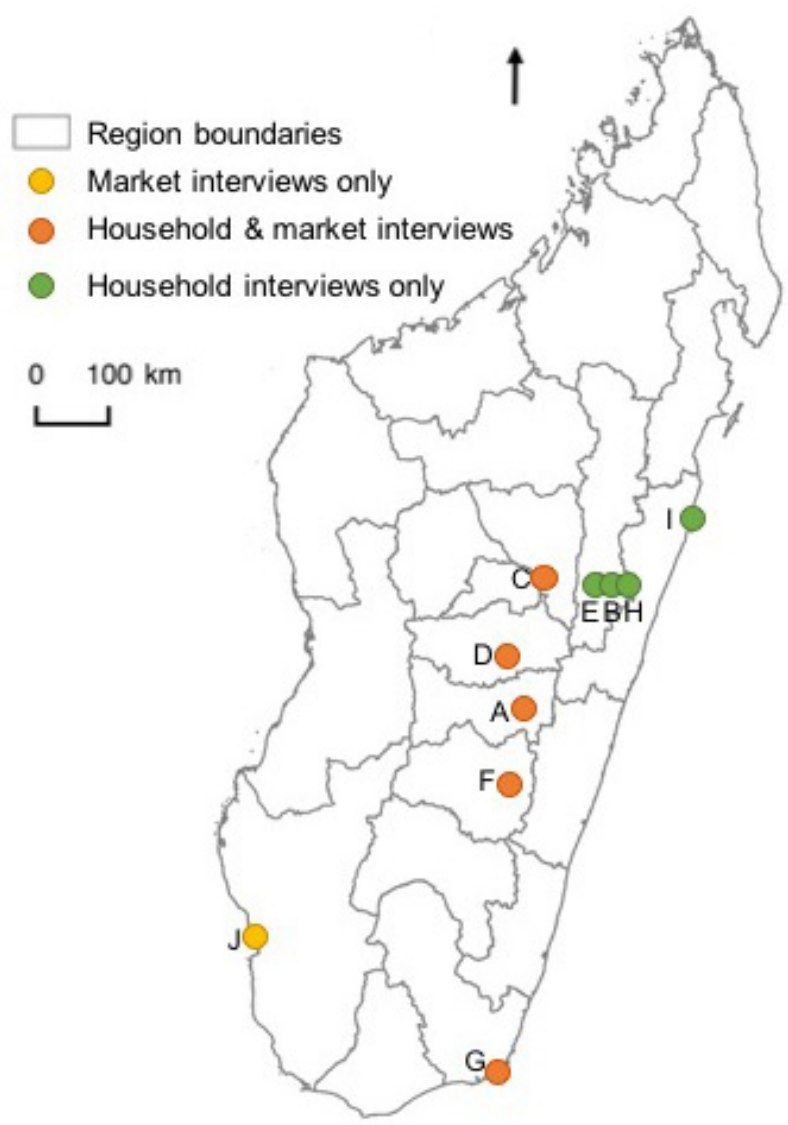

Figure 1. Towns visited for data collection during this study. Administrative boundaries of regions are provided for geographical reference. Letters shown on the map correspond with the town codes in Table S1.

Antananarivo, Toamasina, Antsirabe, Fianarantsoa, Toliara). Towns were located in eight of the country's 22 administrative regions, with at least seven different ethnicities found across the towns. The combined human population of the ten towns was approximately 1.91 million people out of Madagascar's urban population of 7.27 million people, (UNDP 2013). The total population of Madagascar is approximately 22.92 million people (World Bank 2016).

DATA COLLECTION USING HOUSEHOLD SURVEYS. During July and August 2016, we visited households ( $n=440$ ) in nine urban towns (Figure 1, Table S1). For household surveys, following Reuter et al. $(2016 a, b)$ we used random sampling stratified by administrative unit with 5-10 interviews conducted across as many different communes/quarters in each town as time would allow. To ensure independent sampling, only one adult was interviewed per household. If an eligible individual refused to participate or if nobody was present, sampling continued at the next household. Interviews were anonymous and no identifying information was collected. Verbal informed consent was received and interviews were conducted by a two-person team comprised of one international project leader and one trained Malagasy translator.

Interviewees were asked whether they had ever seen a pet parrot. We were clear to use a variety of local words for the words 'pet', 'parrots', and 'lovebirds' (in both Malagasy and French). We asked about parrots and lovebirds separately, as grey-headed lovebirds were not typically considered to be parrots by respondents. We always used translators that were fluent in the local dialect spoken to ensure that the most appropriate common names for the animals were used. We did not provide images of birds to facilitate species identification. However, when an individual did not recognize the local name, we did occasionally show photos of the three species on mobile phone devices. If the answer to our first question was yes, we asked: Where, when, and how many did you see? We recorded information about coracopsis spp. and Agapornis canus separately on our datasheets and in the database used for analysis. Respondents could choose not to answer any question; they could also choose to respond to questions with "I don't know" or "I don't remember".

Similar to other studies on pet ownership in Madagascar (Reuter et al. 2016a), no efforts were made to define or limit the recall period as the purpose of this research was to collect baseline/foundational information about the ownership of pet parrots in Madagascar. Long recall periods are preferred when asking interviewees about rare events (noting the researchers' implicit assumption that ownership of pet parrots in Madagascar would be rare). Long recall periods of rare events can provide more accurate information than the extrapolation of data collected over shorter recall periods (Jenkins et al. 2011, Golden et al. 2013). However, it is important to note that based on the format of the questioning, respondents may have only reported their most recent or the most memorable encounter with a pet coracopsis spp. or A. canus.

Following Reuter et al. (2016a), we did not ask individuals whether they had owned a pet parrot directly, because of the potential for increased interviewee discomfort. We anticipated that some interviewees would be uncomfortable disclosing the ownership of wild animals, like parrots, to foreign researchers who did not have a history of working in the towns where surveys took place (also given that most pet parrots have been illegally extracted from the wild, even if people are generally not aware of environmental laws, Keane et al. 2010). Some interviewees indicated voluntarily that they were current or former owners. In such cases, we asked the following questions: How did you procure the bird? How long did you have your bird? How did ownership end? Sometimes non-owners (e.g., individuals that did not self-report owning the parrot or individuals who clarified that they were not owners) also told us information about how parrots were procured, how long they were owned, and how ownership ended. Studies on the ownership of pet lemurs in Madagascar show evidence that non-owners are able to provide a wide range of information about wild animal pets that they have encountered (Reuter and Schaefer 2016, Reuter et al. 2016a,b).

We did not provide interviewees with a definition of a pet parrot but individuals reported to us on birds that were both caged and not caged (i.e., had clipped feathers or where otherwise kept in an uncaged manner). Pet parrots typically included birds that had a clear human owner (regardless of whether they were caged or not). We excluded birds seen in the wild, zoos, or reserves. The two Coracopsis spp. look physically similar but can be differentiated by their different flight patterns and calls (Forshaw 2010: 146), which may not be observable in caged birds or unknown to individuals that have not observed both species in the wild. Thus, we anticipated a priori that it would be difficult for urban respondents to differentiate between $C$. nigra and $C$. vasa, especially if they only quickly saw the pet parrot. Therefore, aside from differentiating between Coracopsis spp. and Agapornis canus (based on the respondent's use of local or partial scientific names), no further species identification was done. We acknowledge that respondents in more rural areas, or where wild Coracopsis spp. are common, might have been able to differentiate 
between these two species. Given the semi-structured nature of interviews (Rietbergen-McCracken and Narayan 1998), we noted additional information that respondents provided to us (above and beyond their answers to the core questions listed above) as they spoke to us about the Coracopsis spp. and Agapornis canus that they had seen as pets.

In this study, we present data on the procurement, length of ownership, and the end of ownership. Data were reported by individuals that had seen or owned the three target species. Out of 440 household interviews (Table S1), 161 individuals (37 $\pm 11 \%$ of respondents, towns as replicates) reported having seen a Coracopsis spp. in captivity and a total of 39 individuals across all towns volunteered that they were past or current owners of Coracopsis spp. Only 20 individuals in total (4.5\% of all interviewees) had seen an Agapornis canus in captivity. Only one individual interviewed reported having previously owned an A. canus. We present the data on $A$. canus because no other data on their ownership as pets have been published, but the small sample size means that these results should be treated as preliminary and merit further research.

VISITS TO OPEN-AIR MARKETS. During the same time period in which we conducted household surveys, we also opportunistically visited 17 established, well-known, open-air markets in 6 towns (Figure 1., Table S1) at least once when the market was open and at its busiest (e.g., in the morning, during the business week). In some towns, there is a one day of the week ('market day') when more vendors will be selling goods than on other days. We tried to time our visits with these market days but often this was not the case. The time period of our visits coincided with the national 'hunting season' when birds can be extracted legally with permits (Randrianandrianina et al. 2010). Some wild animals are routinely sold (usually dead; sometimes alive) by select vendors in urban markets in Madagascar (the same types of markets that we visited, Reuter et al. 2016b). We are not aware of any studies examining how the volume of wild animals sold (alive or dead) differ in markets in Madagascar between hunting and non-hunting seasons.

When visiting markets, we visually ascertained whether parrots were being sold during our visit. When possible, we also briefly interviewed a selection of sellers in the markets (at least two individuals per market, generally those selling other types of living birds) to understand whether parrots had ever been sold at the market in the past. In addition, these market sellers were asked whether they had ever sold parrots. If the answer was yes, we asked: How did you procure the birds? How much did you sell them for? Additional or more in-depth market visits could not be conducted due to time and resources limitations.

OPPORTUNISTIC DATA COLLECTION. We undertook opportun-

istic data collection on two occasions, when we happened to come across vendors selling parrots. We conducted brief unstructured interviews with these vendors and asked: How did you procure the birds? How much did you sell them for? In the case of the second vendor, it appeared that the individual was trying to solicit a purchase of the birds in question from the foreign researcher; we therefore qualify the price-related data in the results as being the price for 'foreigners' (as opposed to the normal market price).
ANALYSIS. Results are presented as mean values with 95\% confidence intervals (calculated as 1.96 standard deviations from the mean). Sample sizes are typically small and therefore towns are not used as replicates in analyses unless otherwise noted. Price-related data are presented in Malagasy Ariary, with U.S. dollar (USD) equivalents in parentheses, based on the exchange rate of 1 August 2016 (MGA 2983 to USD 1; United Nations Treasury 2016). For comparison, $81.3 \%$ of the population lives on < USD 1.25 per day (UNDP 2013). We present only price data from 2015 and 2016.

\section{RESULTS}

PROCUREMENT OF BIRDS. From the household interviews,

30 owners and 19 non-owners provided information on how Coracopsis spp. were procured. Coracopsis spp. were usually procured via purchase from a third party $(59 \%$ of $n=49)$, although sometimes the bird had been captured by the owner from the wild (22\%), received as a gift (16\%), or an individual had found and hatched parrot eggs (2\%). One respondent noted that the Coracopsis spp. was caught after clearing agricultural fields.

Only two people indicated how Agapornis canus were procured and both respondents said the species was captured from the wild using "sticky traps" (see Discussion). The two street-side vendors of birds opportunistically found by researchers provided information about how they had sourced the birds they were selling. The first vendor, selling both Coracopsis spp. and A. canus, purchased the birds from third-party individual(s) (it was not clear whether these individual(s) were the same individuals extracting birds from the wild). The third-party individuals sourced Coracopsis spp. from a location $117 \mathrm{~km}$ distant from the vendor, though within the habitat range of the species. $A$. canus were sourced by third-party individuals from locations $27 \mathrm{~km}$ and $22 \mathrm{~km}$ distant from the vendor, though not within the habitat range of the species. The second vendor, selling only $A$. canus, had taking them from the wild. Neither capture method nor distance from the source location was revealed.

PURCHASE AND SALE OF BIRDS. From the household interviews, 13 owners and four non-owners could recall the purchase price of the Coracopsis spp. that they had encountered. Four individuals had purchased Coracopsis spp. in 2015 and 2016, paying an average of 16,000 $\pm 9,561$ MGA per bird ( $n=6$; USD $5.36 \pm 3.20$; range: $2,000-35,000 \mathrm{MGA}$ ). Three of the four individuals provided information about the location of purchase; birds were purchased directly from people who had caught them $(n=1)$ and from markets $(n=2)$.

Researchers were not able to visually confirm the sale of parrots during the brief visits to 17 established open-air markets where a range of other animals were sold. However, researchers were informed by vendors that the sale of parrots had happened in the past and would happen again in the future, typically on large market days or on an ad hoc basis. Two individuals interviewed in Antananarivo at open-air markets had previously sold Coracopsis spp. (in 2005 and 2014). These individuals both continued to sell domestic birds (e.g., chickens, ducks) at the market. However, both individuals stopped selling parrots because they were hard to source. One of the two individuals indicated that there was no demand because no one was exporting birds. 
The two street-side vendors of parrots opportunistically found by researchers, were stand-alone vendors, not near existing markets. In both cases, birds were in cages being sold on the side of the road; once in the middle of a major city and the second time along a well-traveled road between two large cities. The first vendor observed was situated at a street-side location selling 20 Agapornis canus (15 in a $\sim 0.03 \mathrm{~m}^{3}$ cage; 5 kept in a $\sim 0.03 \mathrm{~m}^{3}$ cage) and 3 Coracopsis spp. (2 kept in a $\sim 0.06 \mathrm{~m}^{3}$ cage; 1 kept in a $\sim 0.06 \mathrm{~m}^{3}$ cage; Figure 2). The cages were in full sunlight, none had water, and only one cage appeared to have some dried corn and rice available as food (Figure 2). The vendor reported purchasing A. canus for 1,000 MGA (USD 0.34) and selling them for 4,000 MGA each (USD 1.34; selling 6 per month on average), purchasing smaller-bodied Coracopsis spp. for 20,000 MGA (USD 6.70) and selling them for 50,000 MGA (USD 16.76; selling 4 per month), and largerbodied Coracopsis spp. for 30,000 MGA (USD 10.06) and selling them for 60,000 MGA (USD 20.11; selling 1 per month). The second vendor that we observed, was selling three pairs of $A$. canus. Each pair was kept in a $\sim 0.03 \mathrm{~m}^{3}$ cage with no water and seeds/grains for food. The vendor indicated the sale price (likely an elevated sale price for foreigners) would be 100,000 MGA (USD 33.52) per breeding pair.

LENGTH OF OWNERSHIP. Eighteen owners and three nonowners provided estimates for the length of time that a Coracopsis spp. was kept in captivity (Figure 3). The average Coracopsis spp. was kept in captivity for $3.17 \pm 2.51$ years ( $n=21$, range: $0.08-25$ years). No respondents provided information on length of ownership for Agapornis canus.

END OF OWNERSHIP. Twenty-four owners and 14 non-owners were able to provide information on how ownership of Coracopsis spp. ended (Figure 4). Only one respondent provided information on how Agapornis canus ownership ended (the bird flew away).

\section{DISCUSSION}

The purpose of this paper was to increase understanding of the trade of pet parrots in urban areas of Madagascar. Worldwide, nearly $30 \%$ of the 355 species of parrots are currently threatened with extinction (Tella and Hiraldo 2014). The domestic trade of parrots in Madagascar has been poorly studied, therefore it is important to increase research on their extraction and trade to better understand how to enforce bird trade regulations and to create awareness of the impact on wild populations. We found that pet parrots are procured from a series of formal and informal entities with the final owner usually purchasing their parrot from a third party. We hypothesize that most extraction of pet parrots from the wild is illegal. In addition, we found that pet parrots were kept
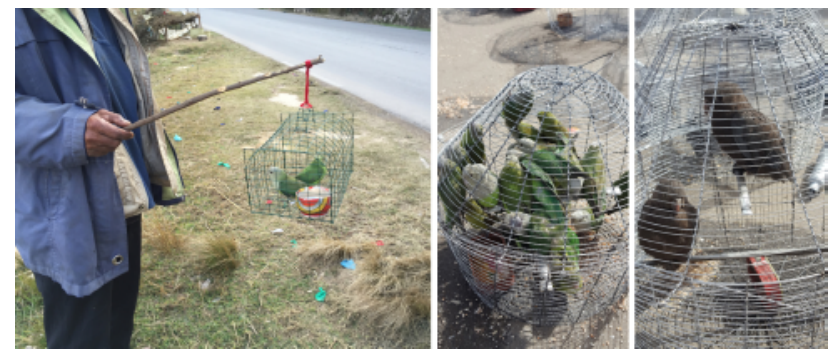

Figure 2. Parrots for sale, as photographed (with permission) at the two vendors that were found during the course of this study. Left and center Agapornis canus, right Coracopsis nigra. alive for relatively short periods of time and that ownership usually ended with the death of the parrot, which is important information should future analyses aim to understand the sustainability of parrot extraction in Madagascar.

PROCUREMENT OF PARROTS. Owners procured their parrots (either purchased from a third party or captured from the wild) at different points along the commodity chain. The trade of parrots in Madagascar is likely similar to the trade of wild animals in Africa, which takes place via a series of formal and informal entities (Bennett 2002, Kümpel et al. 2010, Reuter et al. 2016b). 'Formal' trade typically involves a consistent set of actors and venues (Bowen-Jones et al. 2003) while 'informal' trade structures involve businesses that lack large capital investments, that are ephemeral, or that exist outside government oversight (Benjamin and Mbaye 2014). The legality of trade, and the 'visibility' of trade (e.g., how aware the general public is of the trade), are not equivalent to the formality of the trade. Depending on the context, the trade of an item can be illegal but formalized and visible (Reuter et al. 2016b). Similar to the bushmeat trade in Madagascar, the trade of parrots elsewhere in the world has been conducted through a combination of informal and formal entities. In Mexico, most parrots are opportunistically poached in rural areas by informal entities and then transported to urban areas by more formalized middlemen and sellers (reviewed by Pires and Clarke 2011).

Our data are limited but we document that most birds seem to be purchased by their urban owners from a third-party (as opposed to being personally extracted from the wild; in contrast to pet lemurs in urban areas, Reuter et al. 2016a). These third-parties include both informal and formal entities. For example, the two street-side vendors we opportunistically came across, could be considered 'formal' and 'informal', respectively. The first vendor was seen by researchers selling parrots in the same location multiple times over the months in which data were collected. This vendor regularly sold parrots (providing us with the average number sold per month) and sourced his/her parrots from a third-

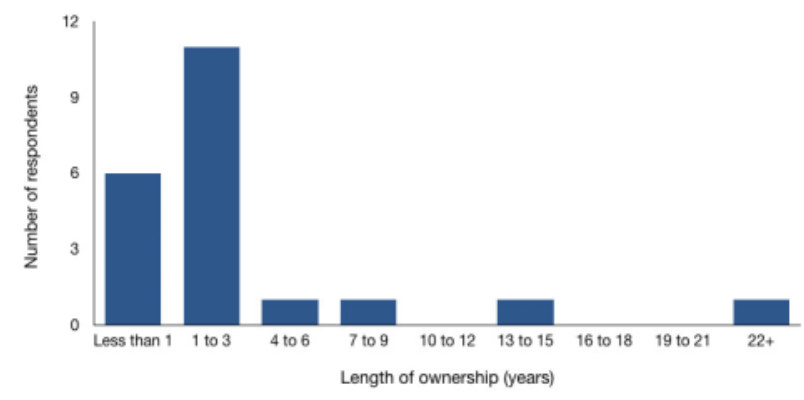

Figure 3. The length of ownership (in years) of Coracopsis spp. as reported by 21 respondents.

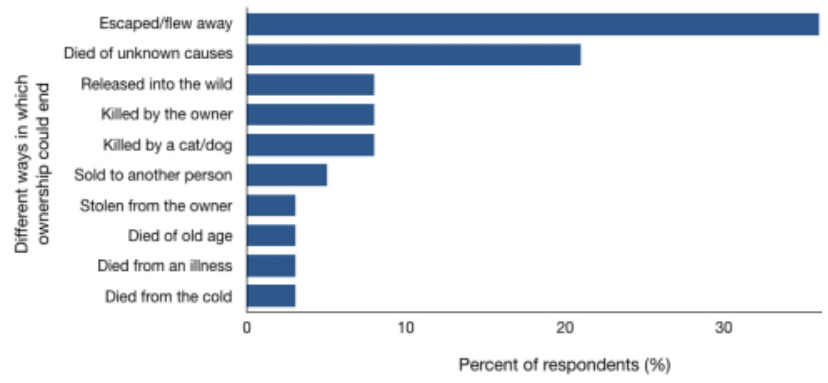

Figure 4. The way in which ownership of Coracopsis spp. ended, as reported by 38 respondents. 
party. The second vendor appeared to be selling the birds on an irregular basis; since he/she extracted them personally from the wild, it might have been an ad hoc method of income. Finally, we document that parrots are sometimes sold at open-air markets though the timing seemed irregular. This is similar to the sale of bushmeat in Madagascar, where large urban markets generally have no more than one individual selling bushmeat on a daily basis with additional individuals selling bushmeat on large 'market days' or when supply is high (Reuter et al. 2016b).

The sale price for Coracopsis spp. (USD $5.36 \pm 3.20$ as reported by Malagasy respondents) is similar to the prices of wild caught parrots sold for domestic trade in other developing areas of the world (e.g. USD 5-10 in Bolivia, reviewed by Pires and Clarke 2011). It is unclear how much the price varies for these species across Madagascar, though we provide evidence that prices for parrots can vary by buyer (e.g., if the buyer is Malagasy or a foreigner). Similarly, the price of a captive lemur varies from USD 1.03-13.65 in Madagascar (Reuter et al. 2016a) depending on the buyer, location, and age/species of the lemur (with prices of up to USD 100 for 'naïve' foreigners). Our data were not sufficient to examine changes in price over time, though this would be interesting to examine in future studies. Legislative measures - like CITES listing a species - have led to price increases in international markets for other animals in the past (reviewed by Tapley et al. 2011)

Some owners do capture their pet parrots directly from the wild. Very few individuals described how parrots were captured (and we did not ask directly regarding this aspect of procurement). In regards to hunting of Coracopsis spp., Gardner and Davies (2014: 24) report that they are "easily catapulted as [they] perch on high, exposed branches". In regards to Agapornis canus, two respondents mentioned "sticky traps"; Gardner and Davies (2014) also report that $A$. canus is captured at lake edges using Folotsia grandiflora (= Cynanchum grandidieri Liede \& Meve Apocynaceae) resin on branches. Plant-based sticky substances have been used to 'sticky-trap' birds in Madagascar, whereby these sticky substances are used as a bird lime (Richardson 1967) and spread onto surfaces where the birds often land, thereby allowing them to be caught alive and relatively unharmed. There are several other types of capture methods that could be used including netting and traps with nooses. Nets are used to capture bats in Madagascar (Reuter et al. 2016b) while nooses (that tighten around the neck or foot of a bird) are described in Gardner and Davis (2014) and have been employed to capture birds. These noose-traps are set in areas where there is a high density of birds and in the case of $A$. canus, fences are sometimes erected to guide the birds towards the traps (Gardner and Davies 2014). It should be noted that no one mentioned the poaching of parrots from their nests.

As noted above (see Methods), the authors hypothesize that most parrots in Madagascar are likely extracted without permits (and therefore illegally). If so, the current protections may be insufficient in ensuring that the extraction of live individuals is done sustainably (Reuter et al. 2017). In other words, the current protections around Madagascar's parrots do not seem to be enforced such that the extraction of animals from the wild is being tracked in any meaningful way. Therefore, it cannot be determined whether extraction rates are sustainable in the long-term. Nationally, there are limited consequences of enforcement for a range of legal and illegal natural resource uses (Sommerville et al. 2010). This is notable as Madagascar is party to CITES (Convention on In- ternational Trade in Endangered Species of Wild Fauna and Flora, CITES 1983) and the CBD (Convention on Biological Diversity, UN 1992) and has therefore agreed to regulate international and domestic trade. If Madagascar is to begin better regulation of the domestic trade of wild animals (both dead and alive), an understanding of the trade and commodity chains are important pieces of information. For example, an in-depth analysis on the commodity chain of bushmeat in Madagascar highlighted several options for regulation at each point on the commodity chain (Reuter et al. 2016b).

LENGTH OF OWNERSHIP. Our study suggests that pet parrots are kept alive in captivity in Madagascar for short periods of time $(3.17 \pm 2.51$ years). However, elsewhere in the world, the maximum lifespan of these species in captivity has been recorded as 38 years for Coracopsis nigra, 29 years for C. vasa, and 16 years for Agapornis canus (Young et al. 2011). This may be because pet parrots in Madagascar are kept in a range of environments that do not allow for adequate movement and nutrition, with some birds showing various stereotypical behaviors (Reuter et al. unpublished data). We have little data as to why some pet parrot owners may be providing low levels of care, but there are several reasons why this may be the case. First, parrot owners may view their pets as having low value (with replacement birds being easily available should the pet parrot die) and may therefore treat them as dispensable (though several owners spoke fondly of their pet parrot). Second, owners of exotic pets often do not know how to best care for exotic pets (Soulsbury et al. 2009). In the United States, pet birds are sometimes ignored or neglected because of behavioral problems (Luescher 2006: 160). In Madagascar, pet lemur owners are not easily able to access information on how to keep these animals as pets (Reuter and Schaefer 2016). This may also be the case with pet parrots.

END OF OWNERSHIP. Our data suggest that the ownership of Coracopsis spp. ends with the death of the parrot $51 \%$ of the time (with various causes of death) and with the escape of the parrot $36 \%$ of the time. We found very little quantitative information on how parrot ownership ends in other areas of the world. One book suggested that in the United States, birds with behavioral problems (even valuable birds) are often neglected or gifted to others (Luescher 2006: 160). This information, along with the data on the average length of ownership, is interesting in regards to the larger question about whether or not the pet parrot trade in Madagascar is sustainable. Though our study cannot answer that question, the information provided here is certainly relevant to those types of analyses.

\section{CONCLUSIONS AND NEXT STEPS}

In this study, we found that pet parrots kept in urban towns in Madagascar are often purchased from third-parties, including markets and individuals that function as both formal and informal traders. We hypothesize that most extraction of parrots is illegal. We further hypothesize that the trade and ownership of parrots is not hidden (meaning, efforts are not made to conceal the ownership of pet parrots by owners). We document that the sale of parrots is often done on an ad hoc basis. For example, we had difficulty locating and interviewing sellers/traders of live parrots using rapid assessment methods. We were only able to speak with live parrot vendors when they were opportunistically found. This 
may be part of the reason why the domestic trade of parrots in Madagascar has received so little attention in the literature.

As evidenced in this study, much remains to be learned about the trade of parrots in Madagascar. For example, in our study, respondents may have under-reported sightings of both coracopsis spp. and Agapornis canus. This could have been due to: 1) the short interview time, 2) the fact that research teams were not well-known to communities being interviewed, 3) that many of the parrots in question were likely extracted illegally (though knowledge of environmental laws is low), and 4) respondents not recognizing which animals/species they were being interviewed about. In addition, a higher sampling effort may have yielded more relevant data for this study, especially if the sale of living parrots is uncommon; for comparison, in one study in Madagascar, less than $1 \%$ of 354 open-air market sellers of meat had sold bushmeat in the three-days prior to being interviewed (Reuter et al. 2016b). As such, there are continued gaps in knowledge that make it difficult to suggest harvest quotas or other quantifiable measures of sustainable extraction of the three species (Beissinger and Bucher 1992). Therefore, we suggest additional research on the extraction and trade of parrots that could help inform where and how often they are captured as pets, in addition to increased understanding about their habitat ranges and total population numbers. Unless the conservation and scientific community turn their attention to Madagascar's parrots, it is likely the Government will continue to be unable to set extraction quotas.

It is clear that, especially in Madagascar, there are a large number of pressing conservation priorities. In this context, it may be counter-intuitive to advocate for additional research and conservation outreach on these three species, all of which are classified as 'Least Concern' on the IUCN RedList (BirdLife International $2016 a, b, c)$. However, the authors would argue that baseline research, perhaps as an addition to ongoing research initiatives (e.g. market surveys, bushmeat studies, habitat surveys) and outreach (e.g., expansion of conservation programming to include birds) would be useful for Madagascar's parrots. This could help ensure that awareness is proactively raised and that, if possible, the conservation community is notified early if there appear to be population declines in the three species (as would be the case if a large number of bird vendors would suddenly have a harder time sourcing parrots from the wild). The lack of studies on similar topics in the past have sometimes masked large conservation issues (e.g., studies on the bushmeat trade in Madagascar in the late 2000's drastically increased awareness of this problem, e.g., Golden 2009, Jenkins et al. 2011).

\section{ACKNOWLEDGEMENTS}

Many thanks to GERP (Groupe d'étude et de recherche sur les primates de Madagascar), Association Mitsinjo, the Sainte Luce Reserve, and to Conservation International for facilitating research in some of the towns visited. Many thanks to Tiana Ratolojanahary, Irène Ramanantenasoa, Housseini Maihidini, Tokihenintsoa Andrianjohaninarivo, Tolotra Fanambinantsoa, Honore Reserva, Olivier Zarason, and Jacky I. A. Youssouff for serving as translators during part of the data collection. Thanks to Toby Schaeffer for the development of maps for this manuscript. We thank host communities for their hospitality. This research was funded by a National Geographic Conservation Trust grant to KER.

\section{REFERENCES}

Andreone, F., Cadle, J. E., Cox, N., Glaw, F., Nussbaum, R. A., et al. 2005. Species review of amphibian extinction risks in Madagascar: conclusions from the Global Amphibian Assessment. Conservation Biology 19, 6: 1790-1802. <http://dx.doi.org/10.1111/j.1523-1739.2005.00249.x>

Annorbah, N. N. D., Collar, N. J. and Marsden, S. J. 2016. Trade and habitat change virtually eliminate the grey parrot Psittacus erithacus from Ghana. Ibis 158, 1: 82-91. <http://dx.doi.org/10.1111/ibi.12332>

Beissinger, S. R. and Bucher, E. H. 1992. Can parrots be conserved through sustainable harvesting? Bioscience 42, 3: 164-173. $<$ http://dx.doi.org/10.2307/1311821>

Benjamin, N. and Mbaye, A. A. 2014. Informality, growth, and development in Africa: WIDER Working Paper 2014/ 052. World Institute for Development Economics Research, Helsinki. Available at <https://goo.gl/UBcSo7>

Bennett, E. L. 2002. Is there a link between wild meat and food security? Conservation Biology 16, 3: 590-592. <http://dx.doi.org/10.1046/j.1523-1739.2002.01637.x>

BirdLife International. 2016a. Coracopsis vasa. The IUCN Red List of Threatened Species 2016: e.T22685261A93065700 <https://goo.gl/QRpZWf> downloaded 21 January 2017.

BirdLife International. 2016b. Coracopsis nigra. The IUCN Red List of Threatened Species 2016: e.T22727885A94964612. <https://g00.g//jZrm81> downloaded 21 January 2017

BirdLife International. 2016c. Agapornis canus. The IUCN Red List of Threatened Species 2016: e.T22685326A93068058. <https://goo.gl/A4y6c5> downloaded 21 January 2017.

BirdLife International. 2017a. Species factsheet: Agapornis canus. <http://datazone.birdlife.org/species/factsheet/22685326> downloaded 21 January 2017.

BirdLife International. 2017. Species factsheet: Coracopsis vasa. <http://datazone.birdlife.org/species/factsheet/22685261> downloaded 21 January 2017.

Bollen, A. and van Elsacker, L. 2004. The feeding ecology of the lesser Vasa Parrot, Coracopsis nigra, in south-eastern Madagascar. Ostrich 75, 3: 141-146. <http://dx.doi.org/10.2989/00306520409485425>

Bowen-Jones, E., Brown, D. and Robinson, E. J. Z. 2003. Economic commodity or environmental crisis? An interdisciplinary approach to analyzing the bushmeat trade in Central and West Africa. Area 35, 4: 390-402. <http://dx.doi.org/10.1111/j.0004-0894.2003.00189.x>

CITES. 1983. Convention on International Trade in Endangered Species of Wild Fauna and Flora. Paper presented at Gaborone. <https://goo.gl/J91J72> downloaded 5 December 2016.

CITES. 2008. Interpretation and Implementation of the Convention. Species Trade and Conservation. Review of Significant Trade. SC57 Doc29.2. Fifty-seventh meeting of the Standing Committee, Geneva, Switzerland.

Dowsett, R. J. 2000. Le statut des Perroquets vasa et noir Coracopsis vasa et C. nigra et de l'inséparable à tête grise Agapornis canus à Madagascar. IUCN Species Survival Commission, Cambridge, UK.

Drews, C. 2001. Wild animals and pets kept in Costa Rican households: Incidence, species, and numbers. Society \& Animals 9, 2: 107-126. Available at <http://www.uky.edu/ jast239/courses/cr/wild.pdf>

Durbin, J. C. 2007. New legislation for the protection of Malagasy species. Lemur News 12: 4-6.

Ekstrom, J. M. M. 2004. Psittaciformes: Coracopsis spp., parrots. In: The Natural History of Madagascar. S. M. Goodman and J. P. Benstead (eds.), pp 1098-1102. The University of Chicago Press, Chicago, USA.

FAO. 2011. Trade in Wild Birds and Related Bird Movements in Latin America and the Caribbean Animal Production and Health Paper No. 166. FAO, Rome. Available at <www.fao.org/docrep/013/i0708e/i0708e00.pdf>

Forshaw, J. M. 2010. Parrots of the World. Princeton University Press, Princeton, USA.

Gardner, C. J. and Davies, Z. 2014. Rural bushmeat consumption within multipleuse protected areas: qualitative evidence from Southwest Madagascar. Human Ecology 42, 1: 21-34. $<$ http://dx.doi.org/10.1007/s10745-013-9629-1> 
Golden, C. D. 2009. Bushmeat hunting and use in the Makira Forest, north-eastern Madagascar: a conservation and livelihoods issue. Oryx 43, 3: 386-392. <http://dx.doi.org/10.1017/S0030605309000131>

Golden, C.D., Wrangham, R.W. and Brashares, J. S. 2013. Assessing the accuracy of interviewed recall for rare, highly seasonal events: the case of wildlife consumption in Madagascar. Animal Conservation 16, 6: 597-603. <http://dx.doi.org/10.1111/acv.12047>

Golden, C. D., Bonds, M. H., Brashares, J. S., Rasolofoniaina, B. J. R. and Kremen, C 2014. Economic valuation of subsistence harvest of wildlife in Madagascar. Conservation Biology 28, 1: 234-243. <http://dx.doi.org/10.1111/cobi.12174>

Grenoble, R. 2013. Ploughshare tortoise smugglers caught with percent of entire species at Thailand airport. <https://goo.gl/hxEHBm> downloaded 2 December 2016.

Hart, J., Hart, T., Salumu, L., Bernard, A., Abani, R. and Martin, R. 2016. Increasing exploitation of grey parrots in eastern DRC drives population declines. Oryx 50, 1: 16. <https://doi.org/10.1017/S0030605315001234>

Hino, T. 2002. Breeding bird community and mixed-species flocking in a deciduous broad-leaved forest in western Madagascar. Ornithological Science 1, 2 : 111-116. <http://doi.org/10.2326/osj.1.111>

Jenkins, R. K. B., Keane, A., Rakotoarivelo, A. R., Rakotomboavonjy, V., Randrianandrianina, F. H., et al. 2011. Analysis of patterns of bushmeat consumption reveals extensive exploitation of protected species in Eastern Madagascar. PLOS ONE 6, 12: e27570. <https://doi.org/10.1371/journal.pone.0027570>

Kümpel, N. F., Milner-Gulland, E. J., Cowlishaw, G. and Rowcliffe, J. M. 2010. Incentives for hunting: the role of bushmeat in the household economy in rural Equatorial Guinea. Human Ecology 38, 2: 251-264. $<$ https://goo.gl/prnv25>

Luescher, A. 2006. Manual of Parrot Behavior. Blackwell Publishing, lowa, USA.

Martin, R. O., Perrin, M. R., Boyes, R. S., Abebe, Y. D., Annorbah, N. D., et al. 2014. Research and conservation of the larger parrots of Africa and Madagascar: a review of knowledge gaps and opportunities. Ostrich 85, 3: 205-233. <http://dx.doi.org/10.2989/00306525.2014.948943>

McBride, P. 1996. Concern for the Greater Vasa Parrot. Psitta-Scene 8: 10. Available at <https://goo.gl/prnv25>

Olah, G., Butchart, S. H. M., Symes, A., Guzman, I. M., Cunningham, R., et al. 2016 Ecological and socio-economic factors affecting extinction risk in parrots. Biodiversity and Conservation 25, 2: 205-223. <http://dx.doi.org/10.1007/s10531-015-1036-Z>

Pires, S. F. and Clarke, R. V. 2011. Sequential foraging, itinerant fences and parrot poaching in Bolivia. The British Journal of Criminology 51, 2: 314-335. <https://doi.org/10.1093/bjc/azq074>

Rakotoarivelo, A. R., Razafimanahaka, J. H., Rabesihanaka, S., Jones, J. P. G. and Jenkins, R. K. B. 2011. Lois et règlements sur la faune sauvage à Madagascar: Progrès accomplis et besoins du future. Madagascar Conservation \& Development 6, 1: 37-44. <http://www.dx.doi.org/10.4314/mcd.v6i1.68063>

Randrianandrianina, F., Racey, P. A. and Jenkins, R. K. B. 2010. Hunting and consumption of mammals and birds by people in urban areas of western Madagascar. Oryx 44, 3: 411-415. <http://www.dx.doi.org/10.1017/S003060531000044X>

Reuter, K. E. and Schaefer, M. S. 2016. Illegal captive lemurs in Madagascar: comparing the use of online and in-person data collection methods. American Journal of Primatology. <http://dx.doi.org/10.1002/ajp.22541>

Reuter, K. E., Gilles, H., Wills, A. R. and Sewall, B. J. 2016a. Live capture and ownership of lemurs in Madagascar: extent and conservation implications. Oryx 50, 2: 344-354. <http://www.dx.doi.org/10.1017/S003060531400074X>

Reuter, K. E., Randell, H., Wills, A. E., Janvier, T. E., Belalahy, T. R. and Sewall, B. J. 2016b. Capture, movement, trade, and consumption of mammals in Madagascar. PLoS ONE 11, 2: e0150305. <https://doi.org/10.1371/journal.pone.0150305>

Reuter, K. E., Rodriguez, L., Hanitriniaina, S. and Schaefer, M. S. 2017. Ownership of parrots in Madagascar: extent and conservation implications. Oryx. <https://dx.doi.org/10.1017/S003060531700093X>
Rietbergen-McCracken, J. and Narayan, D. 1998. Participation and social assessment: tools and techniques. The World Bank, Washington, DC, USA. Available at <https://goo.gl/At3mpz>

Schwitzer, C., King, T., Robsomanitrandrasana, E., Chamberlan, C. and Rasolofoharivelo, T. 2013. Integrating ex situ and in situ conservation of lemurs. In: Lemurs of Madagascar: A Strategy for their Conservation 2013-2016. C. Schwitzer, R. A. Mittermeier, N. Davies, S. Johnson, J. Ratsimbazafy, J. Razafindramanana, E. E. Louis Jr. and S. Rajaobelina (eds.), pp 146-152. IUCN SSC Primate Specialist Group, Bristol Conservation and Science Foundation, and Conservation International, Bristol, UK.

Sommerville, M., Milner-Gulland, E. J., Rahajaharison, M. and Jones, J. P. G. 2010. Impact of a community-based payment for environmental services intervention on forest use in Menabe, Madagascar. Conservation Biology 24, 6: 1488-1498. <https://doi.org/10.1111/j.1523-1739.2010.01526.x>

Soulsbury, C. D., Iossa, G., Kennell, S. and Harris, S. 2009. The welfare and sustainability of primates kept as pets. Journal of Applied Animal Welfare Science 12, 1: 1-20. <http://dx.doi.org/10.1080/10888700802536483>

Tapley, B., Griffiths, R. and Bride, I. 2011. Dynamics of the trade in reptiles and amphibians within the United Kingdom over a ten-year period. The Herpetological Journal 21, 1: 27-34.

Tella, J. L. and Hiraldo, F. 2014. Illegal and legal parrot trade shows a long-term, cross-cultural preference for the most attractive species increasing their risk of extinction. PLOS ONE 9, 9: e107546. <https://doi.org/10.1371/journal.pone.0107546>

UN. 1992. Convention on Biological Diversity. Paper presented at Rio Earth Summit. Rio de Janeiro. <https://www.cbd.int/doc/legal/cbd-en.pdf> downloaded 2 December 2016

UNDP. 2013. Human Development Report 2013: The Rise of the South: Human Progress in a Diverse World. United Nations Development Programme, New York, USA. Available at <https://goo.gl/Fgid4j>

UNEP-WCMC. 2013. A guide to using the CITES Trade Database: Version 8. UNEP World Conservation Monitoring Centre, Cambridge, UK. Available at <https://goo.gl/siadjv>

UNEP-WCMC. 2016. CITES trade statistics derived from the CITES Trade Database. UNEP World Conservation Monitoring Centre, Cambridge, UK. <http://trade.cites.org/> downloaded 2 December 2016.

United Nations Treasury. 2016. UN Operational Rates of Exchange. <https://goo.gl/3dpnyu> accessed 2 December 2016.

Watson, J. E. M., Whittaker, R. J. and Dawson, T. P. 2004. Habitat structure and proximity to forest edge affect the abundance and distribution of forestdependent birds in tropical coastal forests of southeastern Madagascar. Biological Conservation 120, 3: 311-327. <https://doi.org/10.1016/j.biocon.2004.03.004>

World Bank 2017. Available at <https://data.worldbank.org/country/Madagascar>

Young, A. M., Hobson, E. A., Lackey, L. B. and Wright, T. F. 2011. Survival on the ark: life-history trends in captive parrots. Animal Conservation 15, 1: 28-43. $<$ http://dx.doi.org/10.1111/j.1469-1795.2011.00477.x>

\section{SUPPLEMENTARY MATERIAL}

Available online only

Table S1. The ten towns in Madagascar (Figure 1) where data were collected, with population, number of households interviewed, number of individuals who knew someone who owned or had previously owned a bird, number of individuals who themselves owned or had previously owned a bird, number of markets visited, and number of markets where pet parrots (Coracopsis nigra, C. vasa and Agapornis canus) were for sale. (Town codes correlate to the codes shown on Figure 1, population estimates for cities were obtained from http://www.lo.cornell.edu/ilo/data.html, or from local officials, habitat range data taken from BirdLife $(2016 a, b, c)$, *does not include the respondents who had personally owned a parrot)

Richardson, J. 1967. A New Malagasy-English Dictionary. Gregg Press, Farnborough, U.K. 
Table S1. The ten towns in Madagascar (Figure 1) where data were collected, with population, number of households interviewed, number of individuals who knew someone who owned or had previously owned a bird, number of individuals who themselves owned or had previously owned a bird, number of markets visited, and number of markets where pet parrots (Coracopsis nigra, $C$. vasa and Agapornis canus) were for sale. (Town codes correlate to the codes shown on Figure 1, population estimates for cities were obtained from http://www.ilo.cornell.edu/ilo/data.html, or from local officials, habitat range data taken from BirdLife (2016a,b,c), *does not include the respondents who had personally owned a parrot)

\begin{tabular}{|c|c|c|c|c|c|c|c|c|c|c|c|c|c|}
\hline Town & Region & \begin{tabular}{l}
$\frac{1}{8}$ \\
0 \\
\multirow{3}{0}{} \\
0 \\
\end{tabular} & $\begin{array}{l}\text { 흐 } \\
\frac{0}{\overline{0}} \\
\overline{\overline{0}} \\
\overline{0} \\
\end{array}$ & 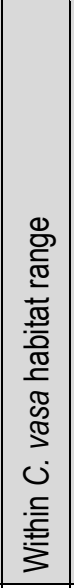 & 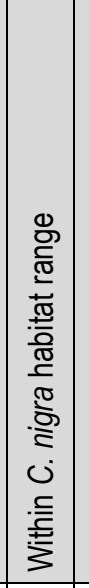 & 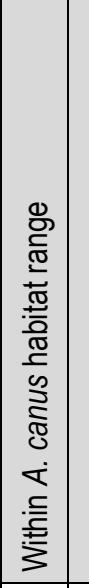 & 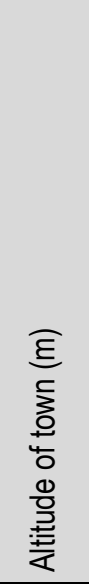 & 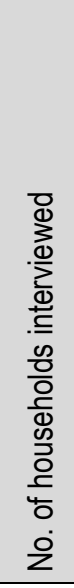 & 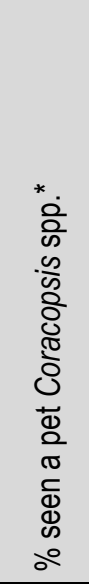 & 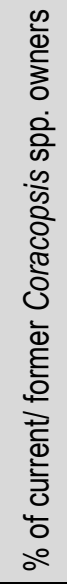 & 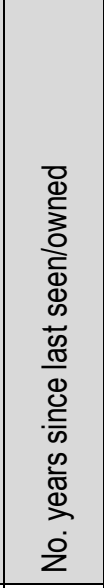 & 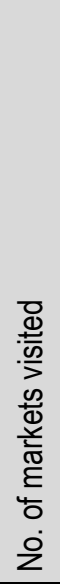 & 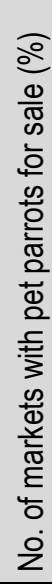 \\
\hline Ambositra & Amoron'i Mania & $A$ & 32818 & no & yes & no & 1318 & 62 & 48 & 21 & $8 \pm 3$ & 2 & 0 \\
\hline Andasibe & Aloatra-Mangoro & B & 12000 & yes & yes & yes & 964 & 53 & 11 & 17 & $5 \pm 5$ & 0 & - \\
\hline Antananarivo & Analamanga & C & 1054649 & no & yes & no & 1276 & 53 & 23 & 11 & $10 \pm 4$ & 4 & 0 \\
\hline Antsirabe & Vakinankaratra & $\mathrm{D}$ & 186253 & no & yes & no & 1500 & 25 & 68 & 0 & $13 \pm 5$ & 5 & 0 \\
\hline Beforona & Aloatra-Mangoro & $E$ & 13000 & yes & yes 1 & yes & 549 & 55 & 38 & 6 & $3 \pm 3$ & 0 & - \\
\hline Fianarantsoa & Haute Matsiatra & $\mathrm{F}$ & 126000 & no & yes & no & 1200 & 32 & 25 & 3 & $24 \pm 6$ & 2 & 0 \\
\hline Tôlanaro & Anosy & $G$ & 46298 & yes & yes & yes & 8 & 50 & 32 & 6 & $2 \pm 2$ & 1 & 0 \\
\hline Moramanga & Aloatra-Mangoro & $\mathrm{H}$ & 40050 & yes & yes & yes & 914 & 60 & 55 & 7 & $3 \pm 3$ & 0 & - \\
\hline Toamasina & Atsinanana & I & 201729 & yes & yes 1 & yes & 11 & 50 & 36 & 0 & $17 \pm 8$ & 0 & - \\
\hline Toliara & Atsimo-Andrefana & $\mathrm{J}$ & 195904 & yes & yes & yes & 8 & 0 & - & - & - & 3 & 0 \\
\hline TOTALS & & & & & & & & 440 & $\begin{array}{c}37 \pm \\
11\end{array}$ & $8 \pm$ & $\begin{array}{c}9 \pm \\
5\end{array}$ & 17 & $\begin{array}{c}0 \pm \\
0\end{array}$ \\
\hline
\end{tabular}

